\title{
Revenue Discrepancy Determinant in Central Java Province (After a Decade of Autonomy and Fiscal Decentralization Implementation)
}

\author{
Hadi Sasana \\ Faculty of Economics and Business, Universitas Diponegoro Jl. Prof. H. Soedarto, SH Semarang, 50275, Indonesia Corresponding
}

\begin{abstract}
This study was to analyze the determinants of revenue discrepancy in the Central Java province. The analysis tool used was panel data regression with fixed effect model method, using secondary data obtained from 35 districts of Central Java Province during 2010-2015. The results indicated that government expenditure and investment variable have positive and significant impact on income inequality in Central Java, while inflation variable has a negative and significant effect on income inequality in Central Java. In addition, economic growth variable and minimum wage of the region have no significant effect on income gap in Central Java
\end{abstract}

Keywords: Income Gap; Government Expenditure; Investment, Inflation; Minimum Wage

\section{Introduction}

In economic development, there is always a dilemma in determining the basic strategy of development; prioritizing economic growth or being equal in income distribution. Income gap is a complicated issue in the economic development experienced by a number of poor and developing countries. The phenomenon of inequality is much experienced by developing countries, but in China, economic development in a big population country with high GDP has led to a significantly improved standard of living of the community[1]. However, the increased quality of life are not evenly distributed to all societies resulting in an income disparity between urban and rural areas.

Since the era of regional autonomy and fiscal decentralization have been implemented in Indonesia in 2001, the reduction of income gap has become the focused effort of local government, especially in Central Java Province. The level of income gap can be measured by using Gini coefficient[2]. The Gini coefficient after a decade of implementing regional autonomy and fiscal decentralization of income gap in Central Java is moderate, but its trend tend to be increasing. One of the factors affecting the income gap is the gap of the economic growth among regions. There is a positive influence between economic growth and inequality[3]. Thus, if an increase in economic growth takes place, an increased gap in economy will also happen as a result of uneven distribution of income. In the short run there is a positive relationship between economic growth and income gap, whereas in the long run the relationship is negative[4]. On the other hand, there is a negative relationship between economic growth and income gap, meaning that an increase in economic growth might decrease income gaps in a region[5]. Also There is a need to improve knowledge on the real impacts of economic development on our ecosystem(s) and citizens' wellbeing to support (local, regional and national) policy decision-making and planning processes [29].

Income inequality is influenced by multidimensional factors both economic and social. Inflation has a negative relationship to income gap and even will increase the rate of the existing income gap[6]. Meanwhile there are two opinions about the relationship between investment and economic disparities[7].

*Corresponding author: hadisasana@live.undip.ac.id 
Furthermore, Nkiru and Daniel in their journal entitled "Impact Government Expenditure on Economic Growth in Nigeria" argued that increased government spending can increase economic growth and reduce income inequalities[8]. However, other opinions suggest that government spending may cause income gap to increase as public expenditure allocations do not touch public's needs. The income disparity is also triggered by the disparity of labor wages among regions. The weakening of wage arrangements leads to an increase in household income inequalities[9], and the increase of the minimum wage may lead to a decrease in income inequality until the wage exceed sits maximum effectiveness. Based on the research and theoretical gap about income discrepancy in a region/country, this study aims to investigate the determinants of the income gap in Central Java Province. The novelty of this study is the investigation of income gaps after a decade of the implementation of regional autonomy and fiscal decentralization in Central Java Province.

The income gap put more pressure on the poor on education and self-quality[10]. In addition to education and self-quality, income disparities also affected public health and trust to the government. Income gap affected poor health of the adolescents. In addition, the income gap also caused social confidence issues from young people to the government[11]. There is also a statement which stated that government spending could affect economic gap[12].

The existing of the socio-economic problems of the community hinted that income gap may also relate to economic growth and economic development of a country. Economic growth positively affects income disparities due to an increase in per capita income of the people working in agriculture that move to industrial sector and cause the level of income gap to increase[13].

Investment is one of the important components in the formation of Gross National Product (GNP). Investment is an activity related to the use of resources for doubling the present time capital, with which the flow of new products will be produced in the future. FDI is an important strategy for economic development because investment can have a positive effect on economic growth, and may also have an impact on reducing income inequalities[7]. There was an important relationship between inequality and inflation[14]. This finding supported the results of that there was a strong positive relationship between inflation and income inequality ${ }^{15}$. Later a study by Monnin indicated that over the long term, inflation and income gaps had U-shaped links in 10 OECD countries.

\section{Methodology}

This study determined income gap as the dependent variable economic growth, and government expenditure, inflation, investment, and minimum wage of regencies/municipalities as the independent variables.
This study used secondary data of 35 districts/cities in Central Java Province during the period of 2010-2015 taken from the Central Bureau of Statistics. The analysis tool used Fixed Effect Model (FEM) with panel data method. The model of this study is as follows:

$$
\begin{aligned}
& \mathrm{IE}=\mathrm{f}(\mathrm{EG}, \mathrm{G}, \mathrm{INF}, \mathrm{INV}, \mathrm{UMK}) \\
& \mathrm{Ln} \quad \mathrm{IE}=\alpha_{0}+\beta 1 \mathrm{EG}_{\mathrm{it}}+\beta 2 \operatorname{lnG}_{\mathrm{it}}+ \\
& \beta 3 \mathrm{INF}_{\mathrm{it}}+\beta 4 \mathrm{INV}_{\mathrm{it}}+\beta 3 \ln _{\mathrm{it}}+\mathrm{u}_{\mathrm{it}}
\end{aligned}
$$

Note: IE is Income Gap; EG is Economic Growth ; $\mathrm{G}$ is Government Expenditures; INF is Inflation; INV is Investment; $\mathrm{W}$ is Regency/Municipality Minimum Wage; ln is natural logarithm; and uis error term.

\section{Discussion}

The aim of this study was to investigate the determinants of income gap in Central Java Province using macroeconomic variables. The results of this study indicated that the government expenditure $(G)$ had a significant positive effect on the income gap. This meant that the increased government spending would increase the income gap of the population in Central Java Province. The result of this study were in line with the finding of fact that local government spending has a positive and significant impact on income inequalities[16]. This showed that government spending could not be enjoyed by all segments of society. Similarly, government spending can lead to an increase in income gap because government spending cannot be well responded by the public[17]. In contrast, Anderson and D'orey's proposed that government spending and income gap have negative relation[18]. Government expenditure can be allocated to empower the poor and channel it to productive sectors so as to enable equal distribution of income. The result of the analysis is Presented on Table I.

Table 1. Regression Estimation Result

\begin{tabular}{|l|l|l|l|l|}
\hline Variable & Coefficient & $\begin{array}{l}\text { Std. } \\
\text { Error }\end{array}$ & t-Statistic & Prob. \\
\hline C & 0.146390 & $\begin{array}{l}0.23967 \\
1\end{array}$ & 0.610796 & 0.5422 \\
\hline EG & 0.004102 & $\begin{array}{l}0.00336 \\
2\end{array}$ & 1.220011 & 0.2242 \\
\hline LnG & 0.054245 & $\begin{array}{l}0.01675 \\
3\end{array}$ & 3.237939 & $0.0014 *$ \\
& & 0.00057 & - & $0.0060^{*}$ \\
\hline INF & -0.001611 & 9 & 2.782527 & ) \\
\hline LnINV & 0.004590 & 0.00108 & 4.247252 & $0.0000^{*}$ \\
& & 1 & & ) \\
\hline LnW & -0.020152 & 0.02432 & - & 0.4085 \\
& & 2 & 0.828551 & \\
\hline
\end{tabular}




\begin{tabular}{|c|c|c|c|c|}
\hline Variable & Coefficient & $\begin{array}{l}\text { Std. } \\
\text { Error }\end{array}$ & t-Statistic & Prob. \\
\hline $\begin{array}{l}\text { R- } \\
\text { Squared }\end{array}$ & 0.646576 & & & \\
\hline $\begin{array}{l}\text { Adj. } \quad \mathrm{R} \\
\text { Squared }\end{array}$ & 0.565497 & & & \\
\hline $\begin{array}{l}\text { F- } \\
\text { Statistic }\end{array}$ & 7.974589 & & & \\
\hline $\begin{array}{l}\text { Prob. F- } \\
\text { Statistic }\end{array}$ & 0.000000 & & & \\
\hline
\end{tabular}

The next finding was that investment had a positive and significant effect on income gap. The result of this study were in line with the findings of previous researchers. Uttama and Luang stating that appropriate economic policies would encourage investment and promote economic growth, but increased the income gap among regions[19]. Investment will increase the income gap as investment increases wages for people with specialized technology expertise[20]. In contrast, Wu and Hsu found that Foreign Direct Investment (FDI) has an influence on income inequality, but the effect is small[21]. Their research indicated that investment in infrastructure proved to reduce the income gap.

The next finding found that inflation has a significant negative effect on the income gap. This meant that any increase in inflation would reduce the income gap among communities in Central Java. Moreover, Shahbaz found that inflation influences the distribution of income between the rich and the poor, and, therefore, the rising inflation will reduce the gap between the poor and the rich[22]. There is also find that inflation has a positive and significant impact on income gaps in 13 European countries[14]. The inflation will be widening the income gap. Moreover, similar issue that inflation has a positive effect on income inequality[23]. The income of the poor decreases when inflation occurs because the minimum real wage also decreases.

The next findings was that economic growth $(\mathrm{G})$ was positively associated with income gaps, but not significant. The estimation result is not significant so it cannot explain the relationship between economic growth and income gap[24]. Furthermore, Barro stated that "in a particular case, there is a stable set of explanatory variables"; so that,the economic growth does not directly affect the income gap[25]. Meanwhile, Yang and Greaney found that the relationship between economic growth and income gap in China, Japan, South Korea, and the United States proved curve $\mathrm{S}$ exists[26]. In short, the economic growth affects the income gap in the four countries. Rubin and Segal's stated that there is a positive relationship between economic growth and income disparities[27].

The subsequent result of this study revealed that the correlation of the minimum wage of the district/city in Central Java Province was negative but not significant to income disparities in Central Java. The minimum wage paid to workers in each region was not a factor affecting the change in income disparity in Central Java. Lin and Yun's stated that the relationship between minimum wage and income gap is negative. The increase in the minimum wage is proven to reduce the income gap in China[28].

\section{Conclusion}

Equal income distribution is a firm effort being operated by the government of Central Java Province. Therefore, it can be concluded that the determinant of income gap in Central Java Province is determined by: the government expenditure, investment., and inflation. The economic growth variables and minimum wages of the regency/municipal have no effect on income gap among regions in Central Java.

The policy implications of the findings of this study are first, the allocation of the government spending in real sector, especially the agricultural sector and the manufacturing industries that absorb the labor force, should be enlarged. Second, the need of incentives for private sectors to increase the equity of investments to various regions togenerate new growth areas in various regions and equally income distribution. Third, controlling the inflation at single digits in the region continues to be pursued because it can encourage economic development and income of the people. For the future, we must look at development infrastructure building in Indonesia, due to the effect of it to environment issue, which is important to realize SDGs.

\section{References and Notes}

1. J. Han, Q. Zhao, M. Zhang, Prspctve in Sci J, China's Income Inequality in The Global Context, 7, 24-29 (2016).

2. M. P. Todaro, and S. Stephen , Poverty, Inequality, and Development", Economic Development $12^{\text {th }}$ Edition, United Kingdom (2015).

3. D. Halter, M. Oechslin, and J. Zweimuller, Eco Grwth $\mathrm{J}$, Inequality and Growth: The Neglected Time Dimension, 19, 81-104 (2014).

4. S. A. Hassan, K. Zaman, and S. Gul, Arab Eco and Buss J, The Relationship between Growth-InequalityPoverty Triangle and Environmental Degradation: Unveiling the Reality, 10, 57-71 (2015).

5. Castello, Eco Inqlty J, Inequality and Growth in Advanced Economies: an Empirical Investigation, 8, 293-321 (2010).

6. M. R. Maurer, and P. A. Yesin, Income Inequality and Inflation Maurer, Working Paper of JEL No. E25, E31, E63 (2004).

7. M. Z. M. Farhan, A. Saini, W. N. W, and S. H. Law, FDI and Income Inequality in ASEAN-5 Countries: A Quantile Regression Approach, Prosiding paper of 
Persidangan Kebangsaan Ekonomi Malaysia Ke-9 No. 2231-962X 601-608 (2014).

8. P. C. Nkiru, and I. C. Daniel, Buss and Mngmnt IJ, Impact Government Expenditure on Economic Growth in Nigeria, 1, 64-71 (2013).

9. D. Gilbert, Income Inequality, International Encyclopedia of The Social and Bahavioral Sciences (2015).

10. F. Cingano, Trends in Income Inequality and Its Impact on Economic Growth, OECD

Social, Employment and Migration.Working Papers, 163, No. H23, J62, O15, O47 (2014).

11. J. J. Rozer, and B. Volker, Soc Sci and Med J, Does Income Inequality Have Lasting Effects on Health and Trust, 37-49 (2016).

12. J. Yang, and M. Qiu, The Impact of Education on Mobile Inequality and Intergenerational Mobility, China Economic Review, 37, 110-125 (2016).

13. B. N. Iyke, and H. S. Yu, Income Inequality and Growth: New Insights from Italia, MPRA Paper, No.78268 (2017).

14. E. Thalassinos, E. Ugurlu, and Y. Muratoglu, Eur Rsrch Stu J, Income Inequality and Inflation in the $E U, \mathbf{X V}, 127-140$ (2012).

15. S. Albanesi, Inflation and Inequality, Monetary Economics J, 54, 1088-1114 (2007).

16. A. E. Sabir, Yustika, Susilo, and G. Maskie, Journal of Applied Economics and Business, Local Government Expenditure, Economic Growth And Income Inequality In South Sulawesi Province, 3, 6173 (2015).

17. I. Claus, J. M. Vazquez, and V. Vulovic, Asian Eco Ppr, Coping with Rising Inequality in Asia: How Effective are Fiscal Policies, 12 (2013).

18. E. Anderson and M. A. D'orey, Journal of Economic Surveys, Does Governmwnt Spending Affect Income Inequality? A Meta-Regression Analysis (2016).

19. N. P. Uttama, and M. F. Luang, Journal of Economic Bulletin, On the Relation Between Foreign Direct Investment and Regional Income Inequality Towards ASEAN's Economic Integration, 33, 2251-2259 (2013).
20. M. Ucal, M. Huseyin Bilgin, and A. A. Haug, Income Inequality and FDI: Evidence with Turkish Data, Discussion Paper on University of Otago Economic Discussion Papers No. 1407 (2014).

21. J. Y. Wu, and C. C. Hsu, Foreign Direct Investment and Income Inequality: Does The Relationship Vary with Absorptive Capacity, Science Direct, 29, 21832189 (2012).

22. M. A. T. Shahbaz, and J.R Sherafatin, Financial Development and Income Inequality: is there any financial Kuznets Curve in Iran?, Working Paper of MPRA Paper No. 4089 (2012).

23. D. A. M. Khattak, and K. Iqbal, Soc Eco Rsrch Acdmy of Soc Sci J, Determining The Relationship between Income Inequality, Economic Growth and Inflation, 1, 104-114 (2014).

24. A. Thabassum, and M.M. Thariq, Economic Growth and Income Inequality Relationship: Role of Credit Market Imperfection, Pakistan Dev Rev J, 47, 727743 (2008).

25. R. Barro, Inequality and Growth Revisited, Working Paper of The Asian Development Bank Paper Series on Regional Economic Integration, No.11 (2008).

26. Y. Yang, and T.M. Greaney, Economic Growth and Income Inequality in The Asia-Pacific Region: A Comparative Study of China, Japan, South Korea and The United States, Asian Eco J, 48, 6-22 (2017).

27. A. Rubin, and D. Segal, The Effects of Economic Growth on Income Inequality in The US. Journal of Macroeconomy, 45, 258-273 (2015).

28. C. Lin, and M. S. Yun, The Effects of the Minimum Wage on Earnings Inequality: Evidence from China, IZA Discussion Paper No. 9715 (2016).

29. T. Alexandre et.al, Economic Growth and Environmental Impacts: An Analysis Based on a Composite Index on Environmental Damage, 76, 121, (2017). 